Bezruchko Oleksandr

Dr.Sc. (Doctor of Science) in Arts, Professor, Professor of the Department of Cinema and Television Art,

Kyiv National University of Culture and Arts ORCID 0000-0001-8360-9388 oleksandr_bezruchko@ukr.net

\title{
LIFE PATH AND A CREATIVE ACTIVITY OF O.S. MOUSSIENKO (ON THE OCCASION OF THE 80TH ANNIVERSARY)
}

The purpose of work is to study and analyze the life path and the creative activity of the famous Ukrainian film critic and the teacher, the professor, the Honored Artist of Ukraine, the corresponding member of the National Academy of Arts of Ukraine O.S. Moussienko. Research methodology consists in application of biographical, historical-cultural, systematic and theoretical and generalizing methods. The marked methodological approaches allow to collect and investigate the contribution made by Oksana Stanislavivna Moussienko in the science of cinema and media pedagogy. The scientific novelty of work lies in the fact that, unfortunately, domestic researchers not often highlight the activities of those, who devoted himself or herself to the study of the cinema process, of all its complexities, contradictions, and achievements. Conclusions. In summary, we would like to note that the set research tasks were fulfilled. The contribution made by Oksana Stanislavivna Moussienko in the science of cinema and media pedagogy was analyzed, the creative and life path of O.S. Moussienko's parents was studied, her track record with pedagogical activities in the field of cinematography at the Cinema Studies Department of Screen Arts Institute of the Kyiv National I. K. Karpenko-Kary Theatre, Cinema and Television University was reconstructed; O.S. Moussienko's best graduate students, Doctors of Philosophy (Ph. D.) on specialty 17.00.04 - Cinematographic Art, Television, who successfully defended their thesis before the Specialized Academic Board of M.T. Rylskyi Institute of Art Studies, Folklore and Ethnology of the National Academy of Sciences of Ukraine were named, and the list of her most important publications in books and magazines in Ukraine and abroad was provided.

Keywords: Oksana Stanislavivna Moussienko, cinema studies, cinema faculty, screen arts pedagogy, cinema studies department, professor, biographical method.

Безручко Олександр Вікторович, доктор мистецтвознавства, профресор, профресор кафедри кінотелемистецтва Київського національного університету культури і мистецтв

\section{Життєвий і творчий шлях О.С. Мусієнко (до 80-річчя від дня народження)}

Мета - проаналізувати життєвий і творчий шлях видатного українського кінознавця та педагога, професора, заслуженого діяча мистецтв України, члена-кореспондента Національної академії мистецтв України О.С. Мусієнко. Методологія дослідження полягає в застосуванні біографічного, історико-культурного, системного та теоретично узагальнюючого методів. Зазначені методологічні підходи дають змогу зібрати та дослідити внесок, зроблений Оксаною Станіславівною Мусієнко в науку про кіно і в медіапедагогіку. Наукова новизна. На жаль, вітчизняні дослідники не так часто висвітлюють діяльність тих, хто присвятив себе вивченню кінопроцесу в усіх його складнощах, протиріччях і досягненнях. Висновки. Проаналізовано внесок, зроблений Оксаною Станіславівною Мусієнко в науку про кіно і в медіапедагогіку, досліджено творчий і життєвий шлях батьків О.С. Мусієнко; реконструйовано сторінки її кінопедагогічної діяльності на кафедрі кінознавства Інституту екранних мистецтв Київського національного університету театру, кіно і телебачення ім. І.К. Карпенка-Карого; названо найкращих аспірантів О.С. Мусієнко, кандидатів мистецтвознавства за спеціальністю 17.00 .04 - кіномистецтво, телебачення, які успішно захистили дисертації у спеціалізованій вченій раді Інституту мистецтвознавства, фольклористики та етнології ім. М.Т. Рильського Національної академії наук України; наведено список найголовніших ії публікації у книжках і журналах в Україні та за кордоном.

Ключові слова: Оксана Станіславівна Мусієнко, кінознавство, кінофакультет, педагогіка екранних мистецтв, кафедра кінознавства, професор, біографічний метод.

Безручко Александр Викторович, доктор искусствоведения, профрессор, профрессор кафедры кинотелеискусства Киевского национального университета культуры и искусств

Жизненный и творческий путь О.С. Мусиенко (к 80-летию со дня рождения)

Цель работы -проанализировать жизненный и творческий путь выдающегося украинского киноведа и педагога, профессора, заслуженного деятеля искусств Украины, члена-корреспондента Национальной академии искусств Украины О. С. Мусиенко. Методология исследования заключается в применении биографического, историко-культурного, систематизационного и теоретически обобщающего методов. Отмеченные методологические подходы позволяют собрать и исследовать вклад, сделанный Оксаной Станиславовной Мусиенко в науку о кино и в медиапедагогику. Научная новизна. К сожалению, отечественные ученые не так часто исследуют деятельность тех, кто посвятил себя изучению кинопроцесса во всех его сложностях, противоречиях и достижениях. Выводы. Подытоживая вышеизложенное, можно отметить, что поставленные научные задания выполнены: проанализирован вклад, сделанный Оксаной Станиславовной Мусиенко в науку о кино и в медиапедагогику, исследован твореский и жизненный путь родителей О.С. Мусиенко; реконструированы страницы ее кинопедагогической деятельности на кафедре киноведения Института экранных искусств Киевского национального университета театра, кино и телевидения им. И.К. Карпенко-Карого; названы лучшие аспиранты О.С. Мусиенко, кандидаты искусствоведения по специальности 17.00.04 - киноискусство, телевидение, которые успешно защитили диссер-

(C) Bezruchko O., 2018 
тации в специализированном ученом совете Института искусствоведения, фольклористики и этнологии им. М. Ф. Рыльського Национальной академии наук Украины; приведен список главных её публикации в книгах и журналах в Украине и за рубежом.

Ключевые слова: Оксана Станиславовна Мусиенко, киноведение, кинофракультет, педагогика экранных искусств, кафедра киноведения, профессор, биографический метод.

Problem statement. Ukrainian cinema studies are rich in names of the prominent history scholars, theorists of screen arts, and cinema teachers, whose contribution to the science of cinema is rich and diverse.

The relevance of this research is due to the fact that, unfortunately, domestic researchers not often highlight the activities of those, who devoted himself to the study of the cinema process, all its complexities, contradictions, and achievements.

Analysis of recent research and publications. The Ukrainian film scholars, with the exception of $\mathrm{V}$. Skurativskyi [16], I. Zubavina [3], N. Moussienko [4], and O. Bezruchko [1; 2] have not conducted an in-depth study of life, creativity and cinema teaching activity of an outstanding Ukrainian movie scholar, a leading national teacher of screen arts, PhD in Arts (1973), Professor (2005), Honored Artist of Ukraine (1998), corresponding member of the National Academy of Arts of Ukraine (2001), laureate of the USSR Filmmaker Union awards (Ukrainian National Filmmakers Union) (1978 and 1987), Oksana Stanislavivna Moussienko, who has been chairing the Cinema Studies Department of the Screen Arts Institute of the Kyiv National I.K. Karpenko-Kary Theatre, Cinema and Television University for more than twenty years and has been teaching there for 50 years.

The scientific tasks of this article are to analyze the contribution made by Oksana Stanislavivna Moussienko in the science of cinema and media pedagogy; to study the creative and life path of O.S. Moussienko's parents; to reconstruct her track record with pedagogical activities in the field of cinematography at the Cinema Studies Department of Screen Arts Institute of the Kyiv National I. K. Karpenko-Kary Theatre, Cinema and Television University; to name O.S. Moussienko's best graduate students, Doctors of Philosophy (Ph. D.) on specialty 17.00.04 - Cinematographic Art, Television, who successfully defended their thesis before the Specialized Academic Board of M.T. Rylskyi Institute of Art Studies, Folklore and Ethnology of the National Academy of Sciences of Ukraine, and to give the list of her most important publications in books and magazines in Ukraine and abroad.

Research methodology consists in application of biographical, historical-cultural, systematic and theoretical and generalizing methods. The marked methodological approaches allow to collect and investigate the contribution made by Oksana Stanislavivna Moussienko in the science of cinema and media pedagogy.

The purpose of the article. Based on the problem, the objective of this research is to investigate and analyze the life path and the creative activity of the famous Ukrainian film critic and the teacher, the professor, the Honored Artist of Ukraine, the corresponding member of the National Academy of Arts of Ukraine O.S. Moussienko.

Statement of basic materials. Oksana Stanislavivna Moussienko's parents were very interesting and talented people, who had made their mark in the Ukrainian art, so let us have a closer look at their fates.

The father, Stanislav Viktorovych Wyshynskyi, has worked at "Bilshovyk" plant and, like most of the young people, was in love with cinema and believed in the revolution ideals. Dovzhenko's "Arsenal" was the concentration of these objects of admiration, for it was an innovative film about revolution, therefore Wyshynskyi not only watched it, but also participated in its discussions.

Due to O.P. Dovzhenko's recommendation, who liked the speech, Stanislav Wyshynskyi started working in Ukrainian cinema, in Odessa and Kyiv film studios (feature films studios), in the editorial board of the Ukrainian newsreel "Soviet Cinema", in Ukrainian cinema education, taught movie history at the Cinema Faculty of the Kyiv State I. K. Karpenko-Kary Theatre Arts Institute (currently the Screen Arts Institute of the Kyiv National I.K. Karpenko-Kary Theatre, Cinema and Television University) and Kyiv State O. Korniychuk Institute of Culture (currently the Kyiv National University of Culture and Arts).

According to O.S. Moussienko, "after the death of the great filmmaker, a museum of Dovzhenko was created at the studio bearing his name. Stanislav Wyshynskyi had also contributed to this noble and important cause" [14].

The mother of our hero, Natalia Hryhorivna Kandyba, worked at the Kyiv State Ivan Franko Academic Theater, were she has played a number of leading roles, and in the Kyiv State Philharmonic, where she had become famous as a talented actress of the conversational genre [5, 22-23].

Artistic genes of parents and their own love for cinema had prompted O.S. Moussienko to devote her life to screen arts and cinema pedagogy.

After graduation with honors in 1960 from Taras Shevchenko State University of Kyiv majoring in Philosophy and History, Oksana Moussienko had been teaching the basics of aesthetic education in vocational school No. 15 for five years.

A tender young teacher was able to not only find a common language with forty radio collectors not attuned to the aesthetic education at all, but also instilled in them love for art, in particular for cinema. Oksana Moussienko recalled that, despite all the difficulties, she made friends with her students, "We went to the 
cinema together, visited museums (Russian, Western Art, and Ukrainian). We even went to football matches. They bought me a ticket, and our whole group cheered the football players. I remember how they wrote me a review for "Electra" filmed by Euripides in 1962 by the Greek director Michael Cacoyannis. Those were great days!" [3, 47]. This is how the pedagogical activity of O.S. Moussienko began.

After finishing the research degree at M.T. Rylskyi Institute of Art Studies, Folklore and Ethnography (IASFE) of the Academy of Sciences of Ukraine (1967-1970), O.S. Moussienko started working as a lecturer at the Cinema Studies Department of the same young Cinema Faculty of the Kyiv State I. K. Karpenko-Kary Theatre Arts Institute.

According to Academician Vadym Skurativskyi, "Oksana Moussienko, the movie scholar, entered the field where, everything had been started almost from the beginning. The young researcher came when a "moving picture» was somewhere around 80 years old. She started primarily with mastering the whole screen heritage of those years, watched and remembered almost all of its frames $<\ldots>$ From classic to other. $<\ldots>$ Oksana Stanislavivna comprehended what she saw very consistently and systematically, and placed it in a certain historical and cultural series-context, thus becoming a master of historical and cultural method applied by her to the realm of cinema of its first century. This method of the researcher inevitably, by its very presence, eliminated the local mental that is unreasonable, barbarism, both militant and any other.

The movie scholar was learning and studying, and afterwards she began to teach others, to teach the contextual nature of each cinema fact, from an individual frame to the major cinema strategies, both national and global" [16, 7].

Oksana Stanislavivna Moussienko repeatedly mentioned that she had received a ticket to the cinema pedagogy from then rector of the Kyiv State I. K. Karpenko-Kary Theatre Arts Institute, a famous Ukrainian movie scholar Ivan Serhiyovych Kornienko, which could understand the people very well, "I am grateful to him for having believed in me; I had just defended my thesis then, and this job has become my life path. I am glad that my hobby and job are the same" [3, 47].

For over 50 years, O.S. Moussienko has been teaching in this institution, having become an associate professor in 1978, and a professor in 2005. From 1991 to 2013 that is for twenty-two years O.S. Moussienko has been chairing the Cinema Studies Department of the Kyiv National I.K. Karpenko-Kary Theatre, Cinema and Television University. It is the only department in Ukraine, where the best domestic cinema teachers educate the future movie scholars.

For many decades Oksana Stanislavivna Moussienko has been teaching the Cinema Faculty (currently the Screen Arts Institute) students to love the history of cinema. According to O.S. Moussienko, "Today my favorite activity is to watch classic movies with my students, to discover them again and again. It is not true that the movie is afraid of time. Real art gains even more sophisticated taste, revealing new and unknown, helping to understand yourself" [3, 47].

As Oksana Stanislavivna Moussienko told to the research author, she had always been trying to include the discussion element in her lectures, since she wants to now the audience feedback and involve the students in the process of reflecting on a particular cinematic phenomenon. Certainly, Moussienko is trying to highlight the major trends of a certain period in the history of cinema, and as regards the details, she always tries to find something that the students are unlikely to find in the all-knowing Internet. This is usually associated with her scientific research [7].

For example, O.S. Moussienko worked at "Cinema" magazine in the All-Ukrainian Picture and Movie Office archives (1925-1933) and could not help sharing with her students the way, say, the Ukrainian filmmakers perceived achievements of the French avant-garde and German expressionism. According to her, it provides greater stereoscopic vision of that uneasy stormy era in the cinema [6].

O.S. Moussienko led numerous creative workshops of the movie scholars, in the classroom and by correspondence, as an artistic director. The experts in screen arts pedagogy know how much hard work and dedication is required in order to bring up the freshmen with blazing eyes, but without skills, and make them real professionals. Professor Moussienko presented her thoughts on the cinema education in some of her articles. Oksana Stanislavivna analyzes the cinema education development trends and those teachers, who are engaged in it.

O.S. Moussienko prepared several graduate students, who successfully defended their thesis before the Specialized Academic Board of M.T. Rylskyi Institute of Art Studies, Folklore and Ethnology of the National Academy of Sciences of Ukraine. In particular, these were Zaza Imad Edd Dean (Syria) - "Cinema of Syria, Lebanon and Palestine (region of Ash-Shaam). History. Becoming and problems of development", I.B. Zubavina - "Structural and Creative Role of a Myth in Ukrainian Cinema", I.Y. Pobedonostseva - "TV Discourse in the Postmodern Cultural Space", O.V. Bezruchko - "O.P. Dovzhenko, a teacher. Creative Search and Method", and V.A. Dovholenko - "Carnivalism Aesthetics in the Movie Artistic Structure".

Oksana Stanislavivna Moussienko is engaged in research of the theory and history of cinema, both domestic and foreign. Her creative works include more than 300 publications, manuals, curricula, and scripts. We would like to mention only the main ones, namely "Screen Image of a Motherland Defender" (1975) [11], "In a Maze of Illusions" (1987) [15], "Tarkovsky and Ideas of the Philosophy of Life" (1995) [17], "The Light of Distant Stars" (1995, co-authored) [13], "A New Wave of French Cinema: Sources, Theoretical Foundation, Masters" (1995, manual) [10], "Cinema and Myths of Totalitarian Society" (1996) [8], "An Attempt of Concep- 
tual Understanding of the History of Cinema in Ukraine" (2000) [12], "Innovative Trends in French Cinema (Second Half of the Twentieth Century)" (2005) [9], "Ukrainian Cinema: Texts and Contexts" (2009) [14], "Modernism VS Avant-garde" (2018).

The distribution of O.S. Moussienko's attention between domestic and foreign cinema can be seen from the structure of her next to last book, "Ukrainian Cinema: Texts and Contexts" [14]. Moussienko was always looking for a global context of Ukrainian cinema and resonance of certain topics, ideas, and images therein. Sometimes she ought to be overtly polemical, as in the case of comparing the German Kammerspiele movies and Ukrainian revolutionary drama ("Two Days", "Night Cab"), to reveal how the avantgarde trends were manifested in the Ukrainian cinema of the 1930s, that is at the times of a seemingly absolute rule of the «socialist realism» method.

For young artists, Teacher's personal example is very important. Oksana Stanislavivna Moussienko has something to be proud of. Her articles are published in many national and foreign professional and specialized publications, she speaks at international and national conferences and round tables dedicated to the history and theory of screen arts, and participates in numerous festivals as a jury member and, certainly, an interested viewer.

Conclusions. In summary, we would like to note that the set research tasks were fulfilled. The contribution made by Oksana Stanislavivna Moussienko in the science of cinema and media pedagogy was analyzed, the creative and life path of O.S. Moussienko's parents was studied, her track record with pedagogical activities in the field of cinematography at the Cinema Studies Department of Screen Arts Institute of the Kyiv National I. K. Karpenko-Kary Theatre, Cinema and Television University was reconstructed; O.S. Moussienko's best graduate students, Doctors of Philosophy (Ph. D.) on specialty 17.00.04 - Cinematographic Art, Television, who successfully defended their thesis before the Specialized Academic Board of M.T. Rylskyi Institute of Art Studies, Folklore and Ethnology of the National Academy of Sciences of Ukraine were named, and the list of her most important publications in books and magazines in Ukraine and abroad was provided.

However, the future research prospects remain extensive, because Oksana Stanislavivna Moussienko is full of energy and creative ideas, continues to educate a new generation of experts of screen arts at the Cinema Studies Department of Screen Arts Institute of the Kyiv National I. K. Karpenko-Kary Theatre, Cinema and Television University.

\section{תimepamypa}

1. Безручко О. Видатний український кінознавець, педагог екранних мистецтв (до 75-річчя від дня народження О.С. Мусієнко) // Культура і життя. 2013. 31 травня. С. 11.

2. Безручко О. В. О. С. Мусієнко: кінознавець, науковець, кінопедагог // Науково-практичні дослідження розвитку творчого процесу в різних видах мистецтва (кінематограф, телебачення, театр, медіа): колективна монографрія [наук. ред. : О. В. Безручко]. Київ : КиМУ, 2014. Т. 1. С. 92-122.

3. Зубавіна І. Мистецтво любити кіно // Кіно-театр. 2008. № 3. С. 46-47.

4. Мусієнко Н. Б. Мусієнко Оксана Станіславівна: матеріали до біографії. Київ : Логос, 2014. 220 с.

5. Мусієнко Н. Служіння рідному слову: (до 90-річчя від дня народження Н. Г. Кандиби) // Актуальні проблеми мистецтвознавства та мистецтвознавчої науки. Мистецькі обрії 2008 / Ін-т пробл. сучас. мистец. АМУ; [редкол.: А.В. Чебикін (голова) та ін.]. Київ : Музична Україна, 2008. Вип. 1 (10). С. 344-348.

6. Мусієнко О. Дискурс українського авангарду на шпальтах часопису «Кіно» // Наук. вісн. КНУТКіТ ім. І. К. Карпенка-Карого / КНУТКіТ ім. І. К. Карпенка-Карого; [редкол.: О. І. Безгін (голова) та ін.]. Київ, 2014. Вип. 15. С. 173-184.

7. Мусієнко О. Інтерв'ю про творчу і кінопедагогічну діяльність, 18 вересня 2013 р. // Приватний архів автора.

8. Мусієнко О. Кіно і міфи тоталітарного суспільства // Зміна парадигми: зб. наук. пр.: [у 2-х ч.] / КДІТМ ім. І. К. Карпенка-Карого; [упоряд. Мусієнко О. С.]. Київ : КДІТМ, 1996. Ч. 2. С. 4-18.

9. Мусієнко О. С. Новаторські течії у французькому кінематографі (друга половина XX століття): [навч. посіб.]; КНУТКіТ ім. І. К. Карпенка-Карого. Київ : Заповіт, 2005. 116 с.

10. Мусієнко О. С. 'Нова хвиля' у фрранцузькому кінематографрі: джерела, теорет. ґрунт, майстри: навч. посіб.; [КДІТМ ім. І. К. Карпенка-Карого]. Київ : М-во культури України, 1995. 87 с.

11. Мусієнко О. С. Образ захисника Вітчизни на екрані. Київ : Наук. думка, 1975. 116 с.

12. Мусієнко О. Спроба концептуального осмислення історії кіно України. Сучасний погляд // Сучасний стан українського мистецтвознавства та шляхи його подальшого розвитку: матеріали наук. конф. / АМУ; [голов. ред. І. Д. Безгін]. Київ : Компас, 2000. С. 121-122.

13. Мусієнко О. С., Мусієнко Н. Б., Слободян В. Р. Світло далеких зірок. Київ : Мистецтво, 1995. 192 с.

14. Мусієнко О. С. Українське кіно: тексти і контекст. Вінниця : Глобус-Прес, 2009. 432 с.

15. Мусієнко О. С. У лабіринті ілюзій: міфи та реальність кінематографу Заходу: (нариси). Київ : МистецтBo, 1987.170 c.

16. Скуратовський В. Із нотаток про одну кінознавчу біографію // Мусієнко Оксана Станіславівна: матеріали до біографії / автор-упорядник Н. Мусієнко. Київ : Логос, 2014. С. 6-10.

17. Musijenko O. Tarkowski i idee "Filozofii bytu"; tł. Marta Sałyga // Kwartalnik Filmowy: Rocznik XVII, (wiosnalato 1995) / Instytut Sztuki Polskiej Akademii Nauk. Warszawa, 1995. N 9/10 (69/70). S. 232-236. 


\section{References}

1. Bezruchko, O. (2013). Prominent Ukrainian movie scholar, screen arts teacher (on the occasion of the 75th anniversary of O.S. Moussienko). Culture and life. May, 31, (p. 11). [in Ukrainian].

2. Bezruchko, O. (2014). O.S. Moussienko: movie scholar, scientist, cinema teacher: Scientific and practical research of the creative process development in different art forms (cinema, television, theater, media). (Vol. 1), (pp. 92122). [in Ukrainian].

3. Zubavina, I (2008). The art to love cinema. Cinema-theatre, № 3, 47. [in Ukrainian]. [in Ukrainian].

4. Moussienko, N.B. (2014). Moussienko Oksana Stanislavivna: biographic materials. (pp. 220). Kyiv: Logos.

5. Moussienko, N. Service to the native word (to the 90th anniversary of the birth of N. G. Kandyba). (2008). Actual problems of art studies and art critic science. Artistic horizons 2008: almanac: theoretical articles. (Issue. 1(10)), (pp. 344-348). Kyiv: Musical Ukraine, [in Ukrainian].

6. Moussienko, O.S. Ukrainian avant-garde discourse on the pages of «Kino» (2014). Scientific announcer of the Kyiv national university of theatre, cinema and television of the name I.K. Karpenko-Kariy: collection of scientific works. (Issue. 15), (pp. 173-184). Kyiv: Kyiv National I. K. Karpenko-Kary Theatre, Cinema and Television University. [in Ukrainian].

7. Moussienko, O.S. (2013). Interview on creative and cinema teaching activities. Author's private archive. September, 18. [in Ukrainian].

8. Moussienko, O.S. (1996). Movies and myths of a totalitarian society. Paradigm Shift: a collection of research papers. (Issue. 2), (pp. 4-18). Kyiv: Kyiv National I. K. Karpenko-Kary Theatre, Cinema and Television University. [in Ukrainian].

9. Moussienko, O.S. (2005). Innovative trends in the French cinema (second half of the 20th century). (pp. 116). Kyiv: Zapovit. [in Ukrainian].

10. Moussienko, O.S. (1995). A "new wave" of French cinema: sources, theoretical foundations, masters: manual. (pp. 87). Kyiv: Ministry of Culture of Ukraine. [in Ukrainian]. Ukrainian]

11. Moussienko, O.S. (1975). Screen image of a Motherland defender. (pp. 116). Kyiv: Naukova Dumka. [in

12. Moussienko, O.S. (2000). An attempt of conceptual understanding of the history of cinema of Ukraine. A modern view. The current state of Ukrainian art history and ways of its further development: conference proceedings: conference proceedings. (pp. 121-122). Kyiv: Kompas. [in Ukrainian].

13. Moussienko, O.S., Moussienko, Slobodyan, V.R. (1995). The light of distant stars. (pp. 192). Kyiv: Mystetstvo. [in Ukrainian]. an].

14. Moussienko, O.S. (2009). Ukrainian cinema: text and context. (pp. 432). Vinnytsya: Globe-press. [in Ukraini-

15. Moussienko, O.S. (1987). In the maze of illusions: myths and reality of the Western cinema: (essays). (pp. 170). Kyiv: Mystetstvo. [in Ukrainian].

16. Skuratovskyi V. (2014). From the notes on a movie scholar's biography: Moussienko Oksana Stanislavivna: biographic materials. (pp. 6-10). Kyiv: Logos. [in Ukrainian].

17. Musijenko, O. (1995). Tarkowski i idee "Filozofii bytu". Kwartalnik Filmowy. (Issue. 9/10 (69/70)), (pp. 232236). Warszawa: Instytut Sztuki Polskiej Akademii Nauk. [in Polish]. 